\title{
Miambera miae n. gen., n. sp. from southern Brazil (Diptera: Chironomidae, Orthocladiinae)
}

\author{
Trond Andersen ${ }^{1}$ \& Humberto Fonseca Mendes ${ }^{2,3}$
}

${ }^{1}$ Department of Natural History, University Museum of Bergen, University of Bergen, P.O. Box 7800,N-5020,Bergen, Norway, e-mail: trond.andersen@zmb.uib.no ${ }^{2}$ Centro de Ciências Naturais e Humanas - CCNH, Universidade Federal do ABC-UFABC, Av. dos Estados, 5001, Bloco A, Torre 3, 6 andar, Bairro Bangu, CEP 09210-580, Santo André - SP, Brazil

${ }^{3}$ Corresponding author: Humberto Fonseca Mendes, e-mail: orthocladiinae@gmail.com

ANDERSEN, T. \& MENDES, H.M. Miambera miae n. gen., n. sp. from southern Brazil (Diptera: Chironomidae, Orthocladiinae). Biota Neotrop. 12(1): http://www.biotaneotropica.org.br/v12n1/en/ abstract?article+bn01312012012

Abstract: Miambera miae n. gen., n. sp. is described and figured based on adult males from Mata Atlântica in southern Brazil. This genus can be separated from other Orthocladiinae based on the combination of hairy eyes; antenna with strong, subapical seta; decumbent acrostichals in the anterior third of scutum; bare wing and squama; $\mathrm{R}_{4+5}$ ending proximal to $\mathrm{M}_{3+4}$; anal point lacking; and tuft of strong, flattened macrotrichia on low, dorsal protuberance of tergite IX.

Keywords: Chironomidae, Orthocladiinae, Miambera, new genus, new species, Brazil, Neotropical region, Mata Atlântica.

ANDERSEN, T. \& MENDES, H.M. Miambera miae n. gen., n. sp. do sul do Brasil (Diptera: Chironomidae: Orthocladiinae). Biota Neotrop. 12(1): http://www.biotaneotropica.org.br/v12n1/pt/ abstract?article+bn01312012012

Resumo: Miambera miae n. gen., n. sp. é descrito e ilustrado com base em machos adultos coletados na Mata Atlântica do sul do Brasil. Este gênero pode ser separado dos demais Orthocladiinae com base na combinação de olhos com pelos entre os omatídeos; antena com seta subapical desenvolvida; acrosticais decumbentes no terço anterior do escudo; asas e squama nuas; $\mathrm{R}_{4+5}$ terminando proximal em relação ao ápice de $\mathrm{M}_{3+4}$; ponta anal ausente e macrotríquios longos e achatados numa pequena protuberância dorsal do tergito IX.

Palavras-chave: Chironomidae, Orthocladiinae, Miambera, gênero novo, espécie nova, Brasil, região Neotropical, Mata Atlântica. 


\section{Introduction}

In their catalog of the Neotropical and Mexican chironomids Spies \& Reiss (1996) listed seven species of Orthocladiinae belonging to five genera from Brazil. Today nearly 100 species of orthoclads have been described or recorded from Brazil and several new genera have been added (see Mendes \& Pinho 2011). However, many new Brazilian Orthocladiinae species still await description. When collecting in Brazil many of the orthoclads encountered do not readily fit into any described genus and below we describe one of these species showing unique character combinations, placing it in a new genus.

\section{Material and Methods}

The specimens were mounted in Canada Balsam following the procedures outlined by Sæther (1969). The general morphology follows Sæther (1980).

The types will be deposited in Museu de Zoologia da Universidade de São Paulo (MZUSP) and in The Department of Natural History, University Museum of Bergen, University of Bergen, Bergen, Norway $(\mathrm{ZMBN})$.

\section{Miambera new genus}

Type species: Miambera miae new species

Etymology: Named after the senior author's four year old grand daughter Mia Rieber-Mohn for all her "help" and suggestions while drawing the species; and mberui, from Tupi meaning midge, mosquito; meaning Mia's midge. Gender of the genus name: feminine.

Diagnostic characters: The combination of hairy eyes; antenna with strong, subapical seta; decumbent acrostichals in the anterior third of scutum; bare wing and squama; $\mathrm{R}_{4+5}$ ending proximal to $\mathrm{M}_{3+4}$; anal point lacking; and tuft of strong, flattened macrotrichia on low dorsal protuberance of tergite IX will separate the genus from all other Orthocladiinae.

Description: Small sized species, wing length 0.74-0.86 mm.

Head. Eye hairy, reniform, without dorsomedian extension. Antenna with ten flagellomeres, in some specimens division of ultimate flagellomere is indicated giving an eleven segmented antenna; sensilla chaetica present on flagellomeres 3 and ultimate; groove beginning at flagellomere 2; plume sparse; with strong subapical seta. Palpomeres normal, third palpomere widened in middle portion, with few sensilla clavata in sensillum coeloconicum. Temporal setae in single row, inner verticals weak, outer verticals strong, postorbitals absent. Frontal tubercle absent. Tentorium and stipes normal. Cibarial pump with anterior margin weakly concave. Clypeus with few setae. Thorax. Antepronotum reduced, with lobes widely separated at anterior margin of scutum. Acrostichals decumbent, apparently uniserial, in anterior third of scutum; dorsocentrals simple, uniserial; prealars simple; supraalar absent. Scutellum with few setae in a single row.

Wing. Membrane without setae, with fine punctuation, microtrichia visible at 400 times magnification. Anal lo be absent. Costa slightly extended, false vein reaching wing tip; $\mathrm{R}_{2+3}$ ending half way between $\mathrm{R}_{1}$ and $\mathrm{R}_{4+5} ; \mathrm{R}_{4+5}$ ending proximal to $\mathrm{M}_{3+4} ; \mathrm{FCu}$ distal to $\mathrm{RM} ; \mathrm{Cu}_{1}$ sinuous. Brachiolum with 1 seta, other veins bare. Squama bare. Sensilla campaniformia about 9 basally, 4 apically, and 5 above seta on brachiolum; 1 on RM; and 1 basally on $\mathrm{R}_{1}$.

Leg. Tibial spurs and comb normal. Tarsal pseudospurs and sensilla chaetica absent. Pulvilli vestigial.

Abdomen. Abdominal setation reduced. Tergite I with few strong median setae, tergites II-VIII with anterior and posterior irregular rows of few strong setae. Sternite I-III bare, sternite IV without or with single strong median seta, sternite V-VII with single to few strong median setae, sternite VIII with few scattered strong setae. Hypopygium. Anal point lacking; tergite IX with tuft of strong, flattened macrotrichia on low, dorsal protuberance and with few setae to each side of dorsal protuberance; laterosternite IX with few setae. Apodemes strongly sclerotized. Phallapodeme and aedeagal lobe well developed. Transverse sternapodeme curved, with strongly developed oral projections. Virga consisting of single, strong, spine-like sclerite. Gonocoxite with well developed inferior volsella with strongly sclerotized, hook-like projection and posterior rounded lobe with weak marginal setae. Gonostylus narrow, covered with long, thin macrotrichia; megaseta normal.

Female, pupa and larva. Unknown.

\section{Systematics}

The genus does not key to any specific genus neither in Cranston et al. (1989) nor in Spies et al. (2009); in the latter it will key to couplet 115 , if the character hairy eyes is ignored and the eyes considered as bare, it will key to couplet 139 .

The genus has such a unique combination of characters that it is difficult to place in any group of genera. The wing resembles that found in the Pseudosmittia Edwards group of genera, while the flattened macrotrichia on tergite IX superficially resemble the flattened setae found on the anal point in Doithrix Sæther et Sublette and Pseudorthocladius Goetghebuer. However, none of the above mentioned genera possess hairy eyes. We therefore refrain from suggesting a placement of the genus until the immature stages and female are known.

\section{Miambera miae new species}

Type material: Holotype male: BRAZIL, Santa Catarina State, Urubici, Morro da Igreja, $28^{\circ} 07.620^{\prime} \mathrm{S}$ and $49^{\circ} 28.788^{\prime} \mathrm{W}, 18.1 x-$ 05.xii.2004, 1822 m a.s.1., Malaise trap, L.C. Pinho \& L.E.M. Bizzo leg. (MZUSP). Paratypes: 34 males, same data as holotype (MZUSP and $\mathrm{ZMBN}$ ).

Etymology: The species is named after Mia Rieber-Mohn, see etymology for genus name.

Diagnostic characters: See diagnostic characters for the genus.

Description: Male $(\mathrm{n}=10$, except when otherwise stated).

Total length 1.08-1.26, $1.17 \mathrm{~mm}$. Wing length 746-857, $791 \mu \mathrm{m}$. Total length/wing length 1.37-1.59, 1.48 (8). Wing length/length of profemur 2.43-2.96, 2.81.

Coloration. Brown, without darker markings; palps slightly lighter than body.

Head (Figure 1). Antenna (Figure 4) with 10 flagellomeres, AR 0.54-0.65; 0.59 (8), ultimate flagellomere 158-194, 176 (8) $\mu \mathrm{m}$ long; if regarded as with 11 flagellomeres, AR 0.57-0.62 (2), ultimate flagellomere 173-176 (2) $\mu \mathrm{m}$ long; subapical seta 20-36, 29 (9) $\mu \mathrm{m}$ long. Temporal setae 6-7, 6 including 3-4, 3 inner verticals and 3-4, 3 outer verticals. Clypeus with 3-6, 5 setae. Tentorium, stipes, and cibarial pump as in Figure 2. Tentorium 61-84, $71 \mu \mathrm{m}$ long, 10-15, $13 \mu \mathrm{m}$ wide; stipes 59-82, $71 \mu \mathrm{m}$ long, 25 (1) $\mu \mathrm{m}$ wide. Palp segment lengths / widths (in $\mu \mathrm{m}$ ): 11-15, 13 / 10-12, 11; 20-29, 25/11-14, 12; 41-50, 44/13-20, 17; 43-57, 49/9-12, 11; 59-88, 76/8-12, 9. Third palpomere (Figure 3 ) with 4-7, 5 sensilla clavata subapically in sensillum coeloconicum, longest 9-11, $10 \mu \mathrm{m}$ long.

Thorax (Figure 5). Antepronotum with 1-3, 2 setae. Dorsocentrals 7-10, 8; acrostichals 2-3, 2, decumbent, in anterior third of the scutum, 


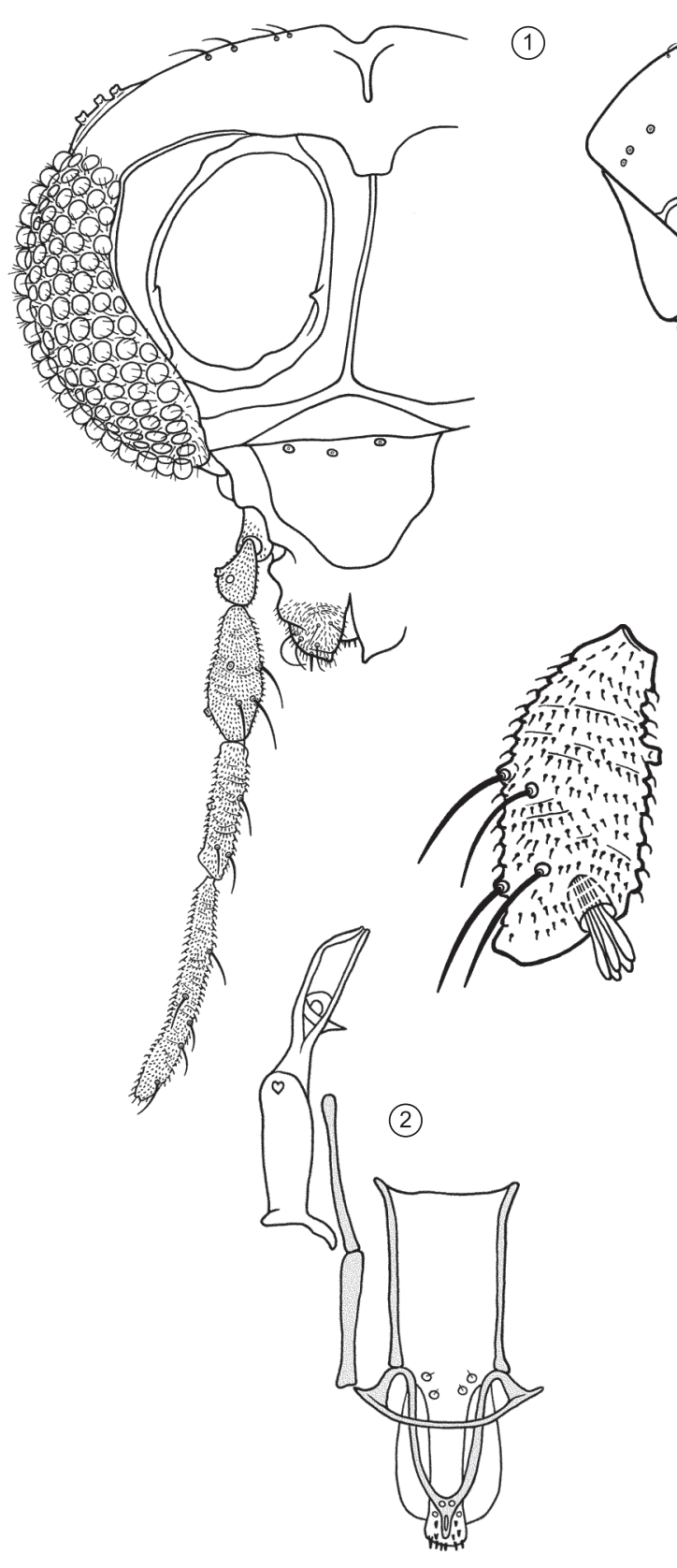

(3)

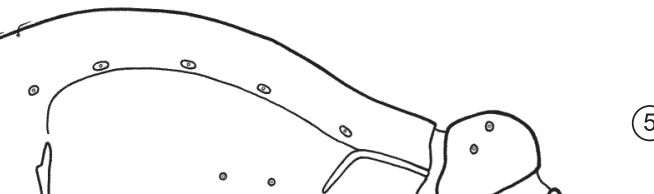

(5)
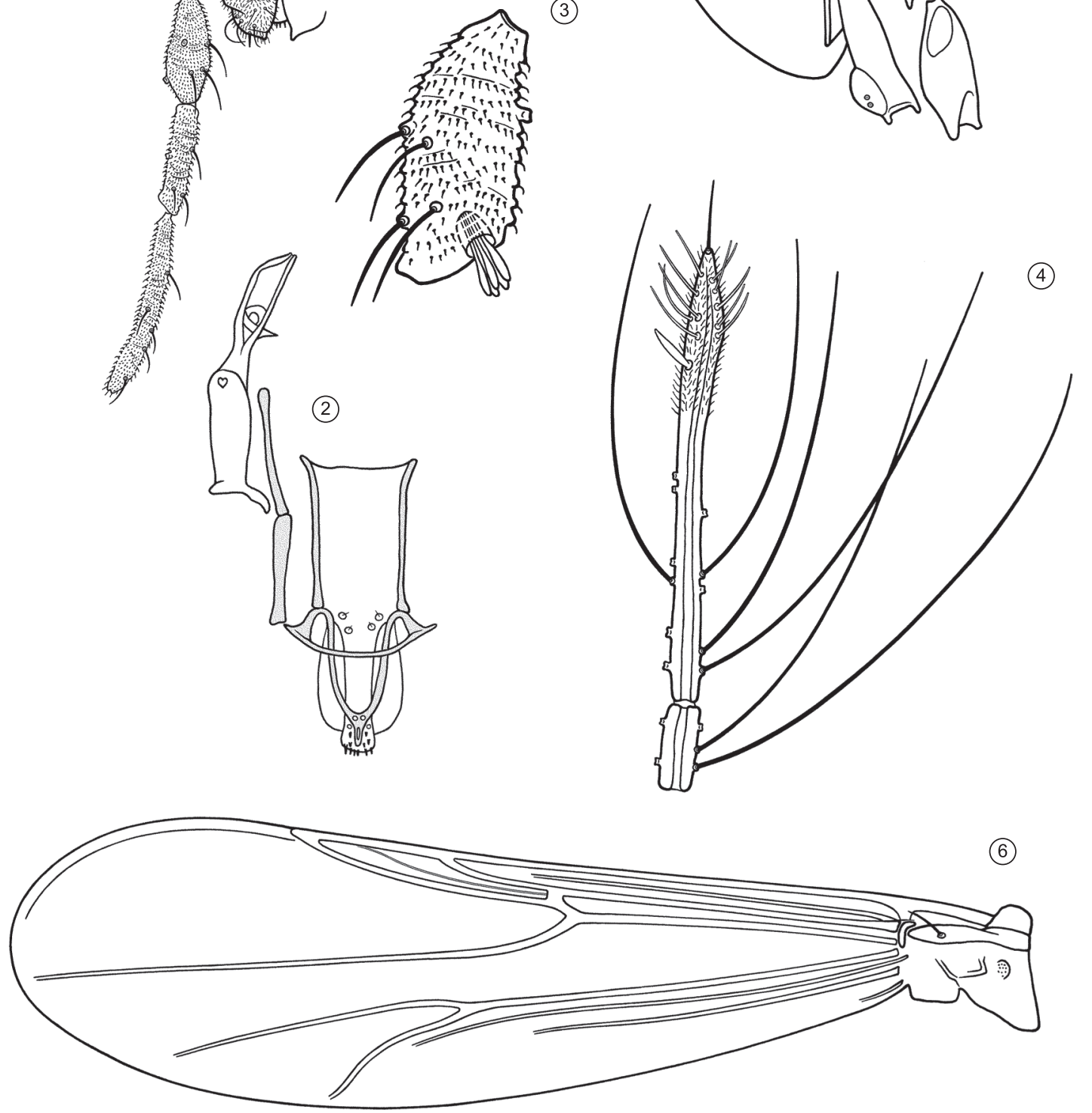

Figures 1-6. Miambera miae n. gen., n. sp., male. 1) Head; 2) Tentorium, stipes and cibarial pump; 3) Third palpomere, ventral view; 4) Ultimate flagellomeres of antenna; 5) Thorax; 6) Wing. 

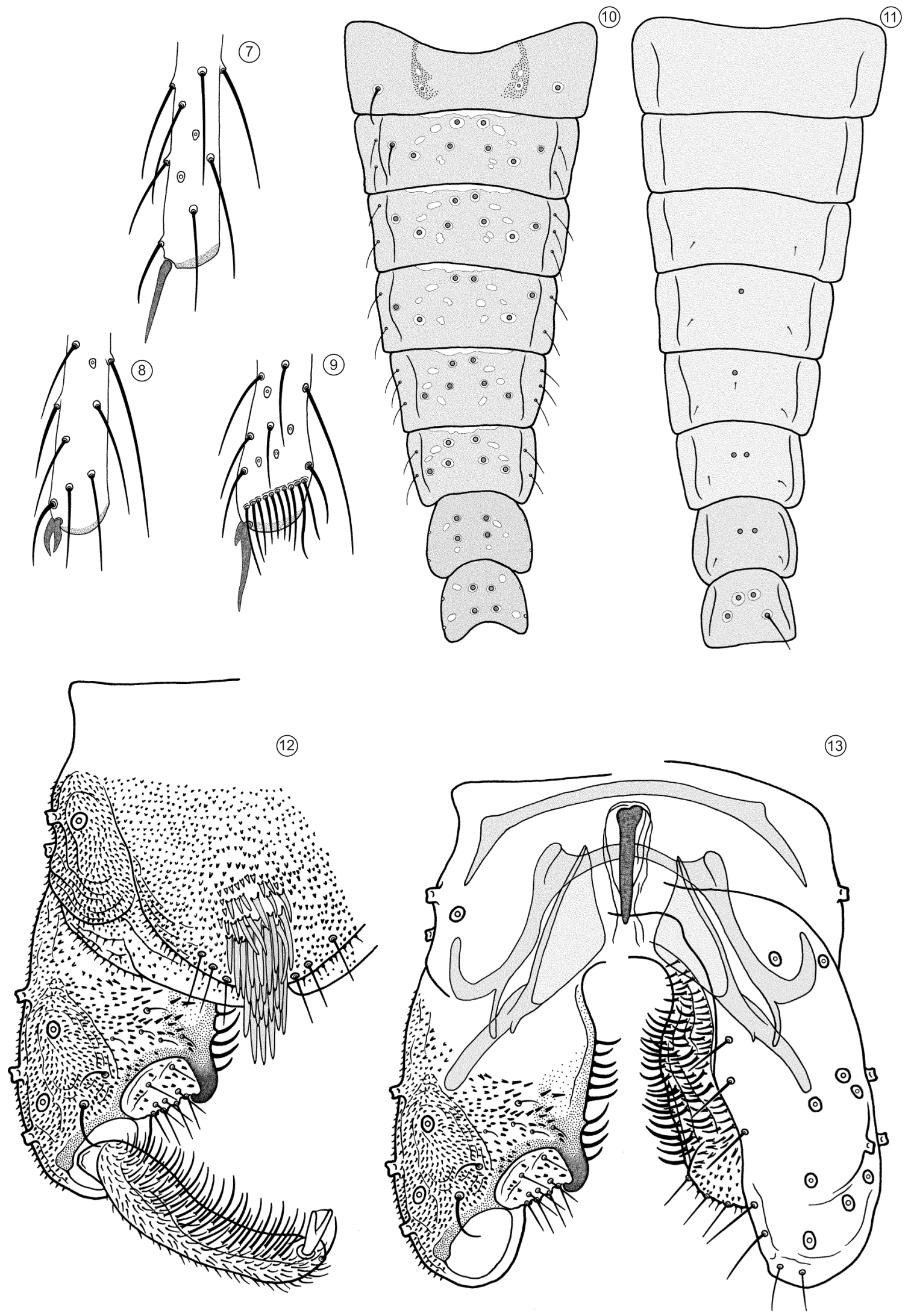

Figures 7-13. Miambera miae n. gen., n. sp., male. 7) Apex of fore tibia; 8) Apex of mid tibia; 9) Apex of hind tibia; 10) Tergites I-VIII; 11) Sternites I-VIII; 12) Hypopygium, dorsal view; 13) Hypopygium with anal point and tergite IX removed, dorsal aspect to the left and ventral aspect to the right. 
Miambera miae new genus, new species

Table 1. Lengths (in $\mu \mathrm{m})$ and proportions of legs of Miambera miae $\mathrm{n}$. gen., $\mathrm{n}$. sp. $(\mathrm{n}=10)$.

\begin{tabular}{ccccccc}
\hline & $\mathbf{f e}$ & $\mathbf{t i}$ & $\mathbf{t a}_{\mathbf{1}}$ & $\mathbf{t a}_{\mathbf{2}}$ & $\mathbf{t a}_{\mathbf{3}}$ & $\mathbf{t a}_{\mathbf{4}}$ \\
\hline p1 & $270-306,288$ & $286-330,312$ & $112-132,121$ & $50-65,59$ & $36-48,45$ & $22-29,25$ \\
p2 & $302-346,323$ & $284-328,306$ & $115-133,124$ & $49-68,59$ & $32-47,42$ & $20-25,22$ \\
p3 & $301-346,324$ & $299-343,323$ & $148-173,164$ & $68-86,81$ & $68-79,76$ & $22-29,25$ \\
\hline \multicolumn{2}{r}{} & $\mathbf{t a}_{\mathbf{5}}$ & $\mathbf{L R}$ & $\mathbf{B V}$ & $\mathbf{S V}$ & $\mathbf{B R}$ \\
\hline p1 & $22-27,25$ & $0.37-0.40,0.38$ & $4.37-4.87,4.62$ & $4.75-5.12,4.89$ & $2.6-3.1,2.9$ \\
p2 & $16-25,21$ & $0.38-0.42,0.41$ & $4.93-5.25,5.09$ & $4.84-5.16,5.01$ & $2.2-2.9,2.5$ \\
p3 & $22-29,24$ & $0.47-0.55,0.51$ & $3.67-4.20,3.91$ & $3.70-4.23,3.94$ & $3.2-4.4,3.7$ \\
\hline
\end{tabular}

apparently in shallow grooves and sometimes difficult to observe; prealars 3. Scutellum with 4 setae.

Wing (Figure 6). VR 1.31-1.39, 1.35. Costal extension 0-16, $8 \mu \mathrm{m}$ long, with false vein reaching wing tip. Brachiolum with 1 seta, remaining veins and cells bare. Squama bare.

Legs (Figures 7-9). Spur of fore tibia 24-32, $28 \mu \mathrm{m}$ long, spurs of mid tibia 10-16, $12 \mu \mathrm{m}$ and 9-11, $10 \mu \mathrm{m}$ long, spurs of hind tibia 27-36, $32 \mu \mathrm{m}$ and 10-14, $11 \mu \mathrm{m}$ long. Width at apex of fore tibia 16-21, $19 \mu \mathrm{m}$, of mid tibia 18-23, $21 \mu \mathrm{m}$, of hind tibia 21-26, $24 \mu \mathrm{m}$. Comb with 10-12, 11 setae, longest 21-25, $23 \mu \mathrm{m}$ long, shortest 15-18, $16 \mu \mathrm{m}$ long. Length and proportions of legs as in Table 1.

Abdomen (Figures 10-11). Strong setae on tergites I-VIII as: 2-4, 4; $2-8,7 ; 5-8,7 ; 6-8,7 ; 6-8,7 ; 3-8,6 ; 4-6,5 ; 4-7,6$. Strong setae on sternites I-VIII as: $0 ; 0 ; 0 ; 0-1,1 ; 1-2,2 ; 2 ; 2 ; 3-6,5$.

Hypopygium (Figures 12-13). Tergite IX with tuft of 20-40 strong, flattened macrotrichia and 4-8, 5 weak setae along posterior margin. Laterosternite IX with 2-3, 2 setae. Transverse sternapodeme curved with strong oral projections, 27-39, $34 \mu \mathrm{m}$ long; phallapodeme 50-60, $55 \mu \mathrm{m}$ long. Virga composed of single spine, 18-23, $20 \mu \mathrm{m}$ long. Gonocoxite 83-95, $87 \mu \mathrm{m}$ long. Gonostylus 43-57, $50 \mu \mathrm{m}$ long; megaseta 7-9, 8 um long. HR 1.58-1.95, 1.74. HV 2.14-2.53, 2.31.

\section{Distribution}

The species is known only from its type locality, Morro da Igreja (Urubici) in Santa Catarina State, southern Brazil, where it was collected in a Malaise trap in an area with cloud forest above 1800 meters altitude. The region belongs to the Brazilian Pine (Araucaria) Forest endemism region of the Mata Atlântica (Silva \& Casteleti, 2003).

\section{Acknowledgements}

We are indebted to Dr. Luiz Carlos Pinho, Universidade Federal de Santa Catarina, for providing us with the material described above, and to Carlos J. E. Lamas, Museu de Zoologia, Universidade de São Paulo and Dr. Dalton S. Amorim, Faculdade de Filosofia Ciências e Letras de Ribeirão Preto, Universidade de São Paulo campus Ribeirão Preto for the loan of additional material from the BIOTA-FAPESP project ["Limites geográficos e fatores causais de endemismo na Floresta Atlântica em Diptera" proc. 03/12074-9 within The Biodiversity Virtual Institute Program (www.biota.org)]. Gladys Ramirez made the slide preparations. The study was partly funded through the Brazilian Research Council of São Paulo State (FAPESP 2011/50162-1).

\section{References}

CRANSTON, P.S., OLIVER, D.R. \& SÆTHER, O.A. 1989. The adult males of Orthocladiinae (Diptera: Chironomidae) of the Holarctic region. Keys and diagnoses. In Chironomidae of the Holarctic region. Keys and diagnoses. Part 3. Adult males (T. Wiederholm, ed.). Ent. Scand. 34(Suppl.): 165-352.

MENDES, H.F. \& PINHO, L.C. 2011. Checklist of the Brazilian Chironomidae species. https://sites.google.com/site/brazilianchironomids/list (último acesso 04/11/2011)

SÆTHER, O.A. 1969. Some Nearctic Podonominae, Diamesinae and Orthocladiinae (Diptera: Chironomidae). Bull. Fish. Res. Bd Canada. 107:1-154.

SÆTHER, O.A. 1980. Glossary of Chironomid morphology terminology (Diptera: Chironomidae). Entomol. Scand. 14(Suppl.):1-51.

SILVA, J.M.C. \& CASTELETI, C.H.M. 2003. Status of the Biodiversity of the Atlantic Forest of Brazil. In The Atlantic Forest of South America: Biodiversity Status, Threats, and Outlook (C. Galindo-Leal \& I.G. Câmara, eds.). Island Press, Washington, p.43-59.

SPIES, M. \& REISS, F. 1996. Catalog and bibliography of Neotropical and Mexican Chironomidae (Insecta, Diptera). Spixiana. 22(Suppl.): 61-119.

SPIES, M., ANDERSEN, T., EPLER, J.H. \& WATSON JUNIOR, C.N. 2009. Chironomidae (Non-biting midges). In Manual of Central American Diptera (B.V. Brown, A. Borkent, J.M. Cumming, D.M. Wood, N.E. Woodley \& M.A. Zumbado, eds.). NRC Research Press, Ottawa, p.437-480. 